\title{
USAGE OF STEEL SLAG AS A CONSTRUCTION MATERIAL AND IN ENVIRONMENTAL APPLICATIONS
}

Scientific paper / Znanstveni rad

Nikolina Stjepanović

(Received: 16 September 2019; accepted: 5 December 2019)

University of Osijek, Department of Biology, MSc

\section{Davorka K. Hackenberger}

University of Osijek, Department of Biology, Associate Professor

Corresponding author: davorka@biologija.unios.hr

\section{Branimir K. Hackenberger}

University of Osijek, Department of Biology, Full Professor

Luca Zelić

University of Osijek, Department of Biology, MSc

\begin{abstract}
Steel slag is a by-product in the production of steel. An increase of its production results in more landfills. It is mostly used as a building material in the construction of roads, where it substitutes natural materials. The use of steel slag in road construction has multiple benefits; both by solving the challenges of waste disposal and preserving environmental resources by moderating the consumption of non-renewable and natural aggregates. Apart from being used as a building material, steel slag is also used in numerous environmental applications, such as soil and water remediation and $\mathrm{CO}_{2}$ sequestration. However, a multidisciplinary environmental impact study of steel slag, particularly regarding both the aquatic and terrestrial organisms, is lacking. Steel slag contains traces of potentially harmful elements that endanger these living organisms, including heavy metals released into the environment. A high pH value can also significantly influence their leaching properties, thereby affecting the organisms in the water and soil. Given the widespread utility of steel slag, it is recommended to make a thorough risk assessment associated with the various environmental applications of this material.
\end{abstract}

Keywords: environmental assessment; road construction; steel slag; leaching; environmental remediation

\section{UPORABA ČELIČANSKE ZGURE: GRAĐEVNI MATERIJAL I PRIMJENA U OKOLIŠU}

Sažetak: Čeličanska zgura je nusproizvod u proizvodnji čelika, a porastom proizvodnje sve je više odlagališta. Čeličanska zgura koristi se kao građevni materijal u gradnji cesta, gdje zamjenjuje prirodne materijale. Uporaba čeličanske zgure u gradnji cesta ima brojne prednosti, kao što je rješavanje problema zbrinjavanja ovoga otpada i smanjivanja štetnog ujjecaja na okoliš zbog smanjene uporabe neobnovljivih prirodnih agregata. Osim kao građevni materijal, čeličanska zgura primjenjuje se u okolišu na različite načine, poput remedijacije ta i vode te sekvestracije $\mathrm{CO}_{2}$. Međutim, multidisciplinarno istraživanje utjecaja čeličanske zgure na okoliš, osobito na kopnene i vodene organizme, nedostaje. Čeličanska zgura sadrži male količine potencijalno toksičnih tvari za organizme, kao što su teški metali koji mogu dospjeti u okoliš. Visoka pH vrijednost također može imati važan utjecaj na procjeđivanje teških metala pa samim time i na organizme u vodi i tu. S obzirom na sve češću uporabu čeličanske zgure, bilo bi korisno napraviti procjenu rizika povezanu s različitim primjenama ovoga materijala na okoliš.

Ključne riječi: ujjecaj na okoliš; gradnja cesta; čeličanska zgura; ispiranje; remedijacija okoliša 


\section{INTRODUCTION}

In the last few decades, steel slag has been widely utilized in the construction industry, particularly in road construction, as a substitute for natural aggregates. However, the use of steel slag in other environmental applications is gaining new research interest. Steel slag is an industrial by-product in the production of steel and classified as a waste material. Approximately 20 million tons of slag is produced annually in Europe alone [1]. On an average, the production of one ton of steel generates 200 (EAF) to $400 \mathrm{~kg}$ (BOF) of by-product, including slag, dust, sludge, and other materials; more than 400 million tons of iron and steel slag is produced annually worldwide. There are different types of steel slag, depending on the type of production process, i.e., type of furnaces used in production, and the cooling process. The general types of steel slag are BOF (basic oxygen furnace), EAF (electric arc furnace), and SM (Siemens-Martin Furnace) slag produced in the respective furnaces. Although steelmaking slag is typically air-cooled, depending on the cooling conditions, the slag is divided into: a) crystalline slag, cooled in ambient conditions; b) granulated slag cooled in water and subjected to air quenching; and c) expanded or foamed slag, cooled in controlled quantities of water, air or steam.

The main chemical compounds of steel slag, as shown in table 1, are calcium, aluminum, magnesium, and iron oxides, and their relative proportions accommodate the process of making steel and cooling rate of the slag [2]. The air-cooled steel slag, which is highly angular in shape, possesses a rough surface texture, high bulk specific gravity, and moderate water absorption, is crushed before its potential application in the building industry.

Table 1 Chemical composition of different type of slag (oxide composition \%)

\begin{tabular}{lllllll}
\hline \multicolumn{7}{c}{ Oxide composition \% } \\
\hline References & Type of slag & $\mathrm{CaO}$ & $\mathrm{SiO}_{2}$ & $\mathrm{Al}_{2} \mathrm{O}_{3}$ & $\mathrm{MgO}$ & $\mathrm{Fe}_{2} \mathrm{O}_{3}$ \\
\hline Das et al. [3] & & 47.9 & 12.2 & 1.2 & 0.8 & - \\
Poh et al. [4] & & 52.5 & 10.8 & 1.3 & 5.04 & 10.01 \\
Juckes et al. [5] & $\mathrm{BOF}$ & $36.4-45.8$ & $10.7-15.2$ & $1-3.4$ & $4.1-7.8$ & - \\
Mo et al. [6] & & 42.42 & 11.04 & 1.61 & 7.19 & 23.73 \\
Mahoutian et al. [7] & & 39.08 & 12.47 & 6.87 & 10.57 & 19.48 \\
Shi et al. [8] & & $30-55$ & $8-20$ & $1-6$ & $5-15$ & - \\
\hline Barra et al. [9] & 29.5 & 16.1 & 7.6 & 5.0 & 32.56 \\
Luxan et al. [10] & 24.4 & 25.4 & 12.2 & 2.9 & - \\
Mahoutian et al. [7] & & 35.23 & 9.41 & 10.78 & 9.77 & 24.22 \\
Manso et al. [11] & EAF & 23.9 & 15.3 & 7.4 & 5.1 & - \\
Shi et al. [8] & & $35-60$ & $9-20$ & $2-9$ & $5-15$ & - \\
Tossavainen et al. [12] & & 38.8 & 14.1 & 6.7 & 3.9 & 20.3 \\
Tsakiridis et al. [13] & & 35.7 & 17.5 & 6.3 & 6.5 & 26.4 \\
\hline Johnson et al. [14] & & 51.05 & 25.80 & 2.31 & 9.32 & 0.72 \\
Mo et al. [6] & & 42.42 & 11.04 & 1.61 & 7.29 & 23.73 \\
Moon and Choi [15] & & 54.30 & 17.70 & 6.40 & 9.20 & 3.00 \\
Xuequan et al. [16] & Steel slag & $45-60$ & $10-15$ & $1-5$ & $3-13$ & $3-9$ \\
\hline
\end{tabular}

\section{STEEL SLAG AS A CONSTRUCTION MATERIAL}

Since the 1880s, when steel slag was first used as a soil enhancer [17], the possibility of its application in various domains has been explored. An extensive literature review on the applications of steel slag in civil engineering is presented in [2], and several studies covering its applications in other branches of civil engineering have been proactively undertaken. Particularly, its use in clinker production is emphasized, as an aggregate in structural concrete and mortar, whose applications are well-known and documented. Recent research also address the advantages of using steel slag as a partial replacement to coarse aggregate in concrete for effective gamma shielding [18].

This study investigates the application of steel slag in road construction for two primary reasons: first, road building, as compared to other sub-disciplines of civil engineering, is the largest consumer of natural resources, 
where steel slag can maximize their preservation; and second, sustainable recycling, that uncovers new material substitutes and their impact on the environment, is essential for road construction materials as pavements and embankment structures are in direct contact with the surrounding soil and potential pollution can infiltrate the groundwater [19].

Steel slag in road construction has multiple benefits, such as tackling the disposal of waste and reducing environmental impact by acting as a reducing substitute for the non-renewable and natural aggregates [20]. This is effectively achieved by applying slag in the unbound base layer of the pavement structure as it entails the maximum thickness (average thickness of the unbound base layer is $20-45 \mathrm{~cm}$ and the asphalt wearing layer is $2-8 \mathrm{~cm}$, for example). Moreover, the slag contained in the unbound base layers achieves higher bearing capacity immediately after compaction and can withstand heavy machinery movement during construction [21]. The interconnectivity between slag grains facilitates optimal load transfer that is beneficial for building roads on weaker soils.

Slag can also be used in the stabilized pavement layers. A small amount of binder, which cannot act independenty, is combined with different types of metallurgical slag (including EAF slag), which enables slag activation [22]. Adding the binder significantly accelerates strength development, which is most pronounced in the first year of material aging. Laboratory tests affirm satisfactory strength characteristics of a mixture of slag, naturally crushed stone, and low grade cement (class $42.5 \mathrm{~N}$ ) [23] as well as that of gravel (as aggregate) and a higher rate but lower strength cement (CEM II B / M (PS), class 32.5 R) [24].

Slag usage in the asphalt layers is limited in the first year of application, owing to the instability of the slag volume, lack of careful materials selection, and incongruous construction methods that may induce cracks and surface protrusions [25-27]. However, appropriate weathering along with the use of finer grain size fractions and coating the steel slag aggregate as a bituminous film can help to curb its expansion and invoke desirable properties for the application in asphalt layers $[25,28]$. Beside volume instability, the presence of free $\mathrm{CaO}$ increases not only the resistance of the bituminous binder to stripping but also the adhesion between the aggregate and binder, which contributes to greater durability of the wearing courses [27, 29]. A major disadvantage of steel slag, as utilized in the construction industry, is the likelihood of volume changes (expansion), considering that substantial proportions of free calcium and magnesium oxides ( $\mathrm{CaO}$ and $\mathrm{MgO})[30,25]$ hydrate under the influence of moisture. Calcium hydrates rapidly cause large volume changes in the first few weeks, while magnesium oxide hydrates contribute gradually to the long-term expansion, lasting up to several years [25]. Exposing the slag to atmospheric conditions for longer durations, called weathering, can effectively control the volume instability. However, newer and faster methods have been discovered, such as aging by steam, which entails covering the slag in tarpaulin/sheet followed by injecting it with steam for a period of 48 hours, revelation, and, lastly, natural cooling [26]. Moreover, preventing the formation of $\mathrm{CaO}$ and $\mathrm{MgO}$ during the steel making process by adding silica sand to the liquid slag and, subsequently, blowing oxygen can help to inhibit expansion [26].

\section{STEEL SLAG IN ENVIRONMENTAL APPLICATIONS}

Apart from the construction field, unearthing the utilities of steel slag in other environmental applications has also generated significant research interest. Figure 1 illustrates the most common environmental applications of steel slag, including remediation of soil, sediment, wastewater, groundwater, and storm water; and as a soil modifier in agriculture [31]. Furthermore, it facilitates the process of mineral carbon sequestration by storing and reducing $\mathrm{CO}_{2}$ [32]. Mineral carbonation or mineral $\mathrm{CO}_{2}$ sequestration involves $\mathrm{CO}_{2}$ reacting with minerals to form geologically stable carbonates, and using steel slag as feedstock is lucrative, given its high calcium oxide content and alkalinity, which enhances $\mathrm{CO}_{2}$ mineralization during the carbonation process. 


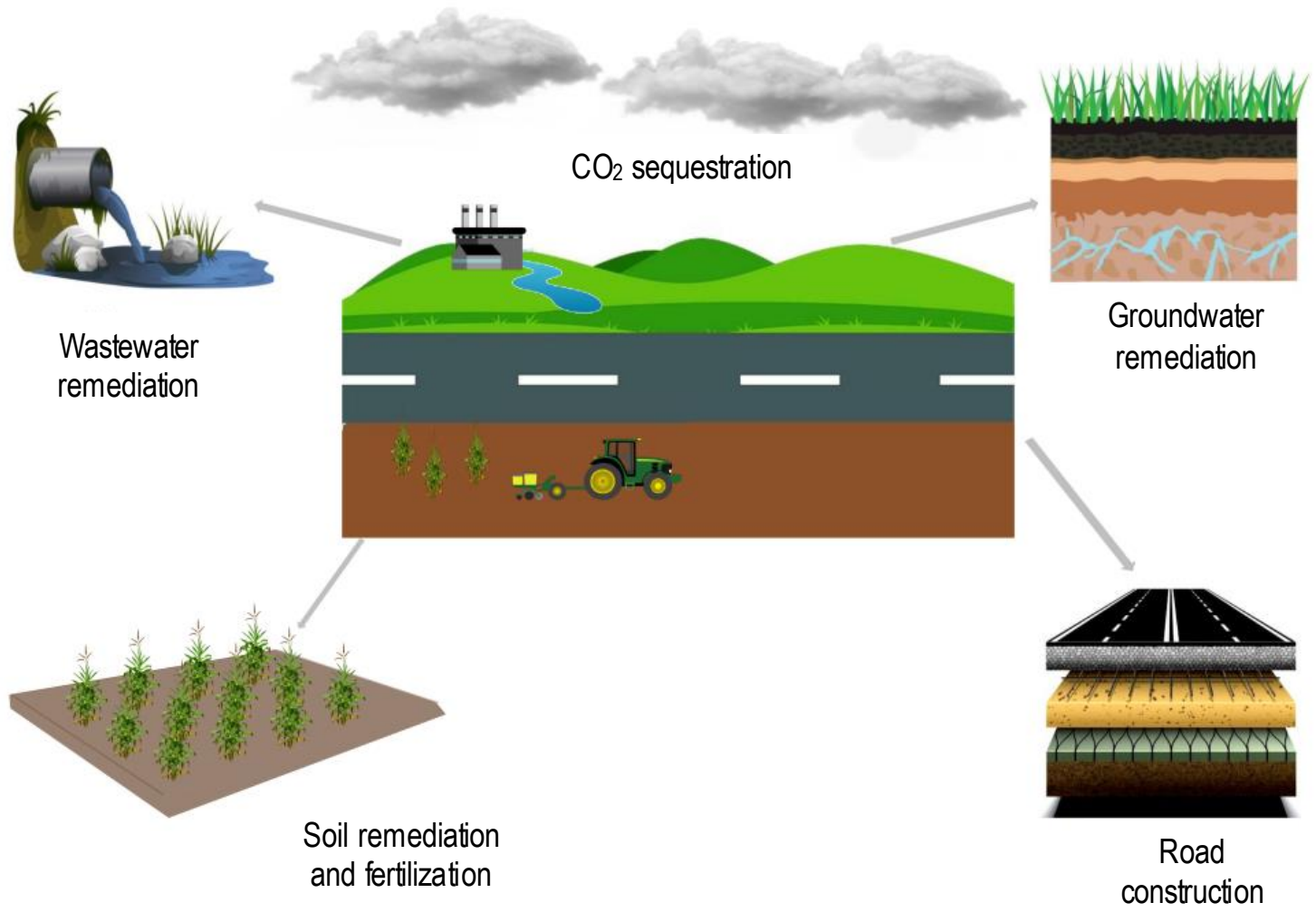

Figure 1 Usage of steel slag in environmental applications

\subsection{Soil remediation and fertilization}

Polluted and unpolluted soils contain a variety of natural compounds. Soil pollution causes a deterioration or loss of one or more soil functions. The process of purifying and revitalizing the soil is known as soil remediation. Soil pollution by heavy metals is particularly concerning owing to its numerous sources, toxicity, non-biodegradability, and accumulative behavior [33]. Remediating such soils is necessary to ensure food security, restore soil nutrients, and increase soil production by mitigating the associated risks [34]. Various industrial by- or co-products, including steel slag, red mud, and fly ash have been proposed as soil amendments [35]. Regulating the solid-solution equilibrium and $\mathrm{pH}$ of the soil is a predominant factor in controlling its metal solubility and bioavailability [36]. These amendments are alkaline and contain a solid phase that enables immobility and adsorption of metals in soil. Steel slag is proposed as a feasible amendment, owing to its physical and chemical properties and the fact that it has been employed, previously, as an amendment and in silicon fertilizers to alleviate the mobility and bioavailability of heavy metals in soils. Steel slag significantly increases the soil $\mathrm{pH}$ and reduces the concentration of $\mathrm{Pb}, \mathrm{Cd}, \mathrm{Cu}$, and $\mathrm{Zn}$ in contaminated soils [35]. The results from a study using steel slag as an amendment and in the silicon fertilizer indicate that it helped to increase the soil $\mathrm{pH}$ and plant-available silicon concentration, and decrease the bioavailability of metals [37]. Additionally, the co-application of ammonium humate and stainless-steel slag decreased the total and available soil cadmium concentrations significantly [38]. The removal of total and available cadmium by the stainless-steel slag may be attributed to the increased $\mathrm{pH}(13.96)$, porosity $(14.50 \%)$, and surface area $\left(2.31 \mathrm{~m}^{2} \mathrm{~g}^{-1}\right)$ essential for satisfactory adsorption. Steel slag is also used to stabilize metals, such as $\mathrm{As}, \mathrm{Pb}$, and $\mathrm{Cu}$ [39].

Researchers have evaluated the benefits of supplementing steel slag as a fertilizer and soil modifier in order to sustain plant growth $[37,40,41]$, where it has catalyzed the rice yield in China by not only increasing the Sicontent in the soil, as required to nurture the plant, but also as a ferbilizer to modify its acidity for paddy culture [37]. According to Gu et al. [42], steel slag can greatly immobilize $\mathrm{Cd}$ in the form of silicates, and stop their uptake in plants. Results from another experiment elucidate the usage of steel slag $\left(3\right.$ and $\left.6 \mathrm{gkg}^{-1}\right)$ in increased soil pH levels from 4.0 to $5.0-6.4,60 \%$ decrease in phytoavailability of heavy metals, and suppressed metal uptake by rice. A study by He et al. [43] demonstrated that adding steel slag as an amendment to the soil effectively and consistently increased brown rice production and ensured grain $\mathrm{Cd}$ levels safe for consumption. 


\subsection{Water remediation}

Water pollution is a major global environmental concern. Remediation of contaminated ground and underground water is becoming a mounted challenge worldwide. Water remediation is the process to treat polluted water by removing the pollutants or converting them into harmless products. It is crucial that wastewater is treated properly before being discharged into the environment. Steel slag is a promising adsorbent for metal and phosphate removal $[31,44-46]$. Previous studies have reported removal rates of $62-79 \%$ and $71-82 \%$ for the total phosphorous and dissolved phosphorous from effluents, respectively. Additionally, steel slag has shown potential in reducing $\mathrm{Cr}(\mathrm{VI})$ from contaminated groundwater via a redox process, where it is used as a reactive permeable barrier [44, 47]. The data presented in Name and Sheridan [48] substantiates the use of BOF slag as a remediation agent to increase soil $\mathrm{pH}$ and reduce the soluble iron and sulphate content. Furthermore, WS-EAF steel slag facilitated the removal of high percentages of $\mathrm{Cd}$ and $\mathrm{Mn}$ ions from aqueous solutions and wastewater, and also highlighted great potential for removal of competitive heavy metal ions in industrial applications [49].

\section{$3.3 \mathrm{CO}_{2}$ sequestration}

Sequestration of $\mathrm{CO}_{2}$ is the most straightforward way to combat the excessive greenhouse effect [50]. Capturing and storing $\mathrm{CO}_{2}$ is considered as an efficient and easily adaptable strategy for $\mathrm{CO}_{2}$ mitigation. Owing to their similarities with natural minerals used in the geological $\mathrm{CO}_{2}$ sequestration process, slags are a sustainable alternative for industrial-scale carbon capture and storage. Steel slag as an industrial waste is a viable form of feedstock for mineral $\mathrm{CO}_{2}$ sequestration because it is well-stocked in alkaline oxides, such as $\mathrm{CaO}$ and $\mathrm{MgO}$, and has an alkaline $\mathrm{pH}$ and low chemical stability. Mineral carbonation involves the dissolution of metal oxides, thereby releasing cations in the solution. These cations then react with the $\mathrm{CO}_{2}$ forming thermodynamically stable carbonates and, consequenty, dispense energy. Sarperi et al. [51] discerned the removal capacity per kilogram of BOF slag under ambiental conditions to be $63 \mathrm{~g}$ of $\mathrm{CO}_{2}$. The slag exhibited better performance in terms of carbonation due to its physical characteristics, such as relatively high surface area and $\mathrm{pH}$ value. The carbonation reaction occurred in two steps: the steel slag particles facilitated calcium leaching into the solution, followed by calcite precipitation on the surface of particles [52]. Kasina et al. [53] reported an increase in the carbonate content in steel slag from 0.8 to $1.4 \mathrm{wt} \%$, and BOF slag from 0.6 to $2.6 \mathrm{wt} \%$. The degree of carbonation is attributed to the mineral composition and their varying solubility. Carbon dioxide can be captured using, both, wet (solution-based) and dry (air) methods. According to Yu and Wang [54] capturing carbon dioxide from air depends on the temperature, $\mathrm{CO}_{2}$ concentrations, and atmospheric pressure. Their results indicate that the carbonation reaction of steel slag is controlled not only by the reaction kinetics but also the diffusion of the reactive $\mathrm{CO}_{2}$. A direct $\mathrm{CO}_{2}$ reduction annually from flue gas was estimated at $0.137 \mathrm{Gt} \mathrm{CO}_{2}$ when iron and steel slags were applied for $\mathrm{CO}_{2}$ mineralization [55].

\section{CONSIDERATIONS FOR ENVIRONMENTALUSAGE}

Before steel slag can be utilized as an aggregate in road construction and environmental applications, such as soil and water remediation, $\mathrm{CO}_{2}$ sequestration, and soil ferbilization, a complete environmental risk assessment is warranted. Although steel slag is not considered hazardous, it is important to investigate the environmental impact, such as changes in the chemical content and properties of the slag in environmental conditions due to heavy metal content, particularly leachable quantities, changes in $\mathrm{pH}$ value, and effect on living organisms [54].

\subsection{Heavy metal content}

Certain types of steel slags contain traces of potentially mobile and toxic elements, such as $\mathrm{Cr}, \mathrm{Ni}, \mathrm{Mn}, \mathrm{V}$, and $\mathrm{Mo}$. Additionally, As, Cd, Co, Pb, Sb, and $\mathrm{Zn}$ can also be found $[56,57]$. It is essential to predict the long-term behavior of steel slag by determining the rate and mechanisms of the metal release. The toxicity and mobility of these harmful elements depends on factors, such as oxidation state, molecular geometry, and environmental conditions [58]. Chromium is a redox active metal that persists as either $\mathrm{Cr}(\mathrm{III})$ or $\mathrm{Cr}(\mathrm{VII})$ in the environment. Unlike $\mathrm{Cr}(\mathrm{III})$, which is an essential nutrient for plants and has low toxicity at higher content levels, $\mathrm{Cr}(\mathrm{VI})$ is toxic for plants. Soils with high content percentages of oxidized manganese and other electron receptors promote the oxidation of $\mathrm{Cr}^{3+}$ to $\mathrm{CrO}_{4}{ }^{2-}$. 
Moreover, the latter oxidation state occurs among leachates in the presence of oxygenated water (with pH levels above 5), given its stability under these conditions. Vanadium exists in oxidation states ranging from 0 to +5 , with the most common valence states being $+3,+4$, and +5 . The toxicity of vanadium increase usually as a valance increases proportionally with the valence state. Therefore, an accurate estimation of these oxidation states is vital. Chromium is released less than $0.02 \%$ of the total content, while $V$ is released between 0.4 and $0.5 \%$, even during short leaching periods [58]. A study on the leaching process of both these toxic trace elements from the slag when exposed to air currents (dry) and carbonated water (wet) indicated that the treated slag showed leaching levels of below $1 \%$ for both elements [59]. It is relevant to known the chemical composition of these leachates and their behavior as the total heavy metal content is not entirely representative of the total released concentration in the environment. The concentration of heavy metals in a leachate depends on the way an element is incorporated into the aggregate matrix [60]. Furthermore, the chemical composition of the leachate can only be used to predict total heavy metal content, as the individual proportions of heavy metal content is not proportional to their total content. However, the individual quantity of these potentally environmentally toxic elements is important in determining the application rate of slag in the environmental applications.

\subsection{Leaching}

Leaching properties of a material are directly related to the risk of the material releasing harmful substances into the environment. Therefore, a risk assessment supported by the material characterization with leaching and ecotoxicological testing is necessary. One of the most significant environmental impacts of administering and reusing steel slags is the leaching effect, caused by the soluble slag matrix in contact with the soil that is exposed to rainwater or in permanent contact with the surface and seawater. Leaching tests are conducted to estimate the release potential of constituents from the associated waste materials. Leaching processes comprise contact between a liquid and solid material, where the partial dissolution of certain components occurs [57]. Several factors can influence the process viz., physical factors, including particle size, temperature, porosity, permeability, hydrogeological environment; and chemical factors, including $\mathrm{pH}$, redox potential, kinetics, adsorption process, etc. The process also comprises heterogeneous reactions, which may or may not be reversible, and quick or slow. Additionally, after post the metal recovery process, $25 \%$ of slag is rendered as a fine-grained powder, which is unusable without treatment, given the elevated leaching of chromium and molybdenum [61].

\section{$4.3 \mathrm{pH}$ value}

$\mathrm{pH}$ is a major parameter controlling leaching in many elements. Steel-industry slags are alkaline and produce water leachates with a pH value between 9-11 [62]. A high pH value can adversely affect the environment and living organisms. According to Piatak et al. [63], alkaline leachates result from the dissolution of Ca silicates, oxides, and carbonates, and therefore, an alkaline $\mathrm{pH}$ can be harmful for not only the environment but also aquatic life. It increases chemical oxygen demand, sulphate content, and salinity. Elevated $\mathrm{pH}$ levels reduce mobility (leachability) of metals in the slag in or near surface water and groundwater bodies that have limited dilution volume, thereby emerging as an impediment in its application [62]. It is expected that the alkaline leachate does not react with huge water bodies or acidic soils, as it gets neutralized under these conditions.

\subsection{Impact on living organisms}

Steel slag is used in a wide range of environmental applications as well as road construction. However, there is a limited number of multidisciplinary studies on how it affects living organisms, positively or otherwise. The heavy metal content in steel slag is non-biodegradable and tends to accumulate in the food chain, causing various disorders among living organisms. Numerous studies have examined the impact of slags on water organisms [6466]. Ringelband [64] claims that the vanadium found in slag stones effects the population growth of the brackish water hydroid Cordylophora caspia at various salinities. Takahashi and Yokoyama [65] investigated the adverse effects of EAF steel slag on Chlorella algae. An analysis of the algal cells treated with eluate revealed no lethality (cytotoxicity) or growth inhibition; instead, it enhanced algal growth. The apparent cytotoxicity in microalgae (Chlorella sp.), cladocerans (Ceriodaphnia dubia), and bacteria (Vibrio fischeri) was attributed to the elemental composition of the slag [66]. Slag leachates with the highest concentrations of dissolved elements were the most 
toxic $(10 \%$ effective concentration [EC10] 1\%), whereas those with the lowest concentrations were the least toxic (EC10 63-85\%) [66]. These leachates were not tested at their natural pH values, which was higher than acceptable for algal growth, cladoceran survival, and Microtox testing. Invertebrates, such as earthworms, possess limited movement and can spend their entire lives within the area of slag application, so long as the nutrient and $\mathrm{pH}$ conditions permit. The extracts of steel slag did not demonstrate any significant changes in the activities of the molecular biomarker, $\mathrm{AChE}$, in the earthworm Eisenia fetida [60]. In humans, a study investigating the potential health adversities associated with the environmental applications of steel-industry slag revealed no significant hazards [63]. Nevertheless, the advantages and disadvantages of employing slags in the environment is reliant on the application rate, which needs to be predetermined for each type of slag as their compositions vary (Table 1), particularly in trace elements. Similarly, in another experiment, red mud (an alkaline bauxite by-product) was used as a soil amendment. The inherent differences in the composition of red muds from different sites affected the reproduction of earthworms and, accordingly, required different application rates to protect the soil biota [67].

\section{CONCLUSION}

The results from various environmental applications of steel slag appear to be promising and result in a significant reduction of steel slag deposition as more than a waste material. However, a thorough ecological risk assessment should be recommended supported by the characterization of slags and their leachates, prior to the environmental application. There is a lack of data and multidisciplinary approaches concerning how steel slag impacts living organisms and the environment. The chemical characterization and soil pore-water measurements should not be used as sole determinants, given that mixtures of metals, even in small quantities, can inevitably harm living organisms. However, research on the usage of steel slag in construction and environmental applications is encouraged, as it is unlikely that the steel production will stop.

\section{References}

[1] Liu, C.; Guo, M.; Pandelaers, L.; Blanpain, B.; Huang, S. 2016: Stabilization of free lime in BOF slag by melting and solidification in air, Metallurgical and Materials Transactions B, 47 (6), pp. 3237-3240, https://doi.org/10.1007/s11663016-0809-4

[2] Netinger Grubeša, l.; Barišić, l.; Fucic, A.; Bansode, S. S. 2016: Characteristics and uses of steel slag in building construction, Woodhead Publishing, https://doi.org/10.1016/C2014-0-03994-9

[3] Das, B.; Prakash, S.; Reddy, P. S. R.; Misra, V. N. 2007: An overview of utilization of slag and sludge from steel industries, Resources, Conservation and Recycling, 50 (1), pp. 40-57, https://doi.org/10.1016/i.resconrec.2006.05.008

[4] Poh, H. Y.; Ghataora, G. S.; Ghazireh, N. 2006: Soil stabilization using basic oxygen steel slag fines, Journal of Materials in Civil Engineering, 18 (2), pp. 229-240, https://doi.org/10.1061/(ASCE)0899-1561(2006)18:2(229)

[5] Juckes, L. M. 2003: The volume stability of modern steelmaking slags, Mineral Processing and Extractive Metallurgy, 112 (3), pp. 177-197, https://doi.org/10.1179/037195503225003708

[6] Mo, L.; Zhang, F.; Deng, M. 2016: Mechanical performance and microstructure of the calcium carbonate binders produced by carbonating steel slag paste under $\mathrm{CO}_{2}$ curing, Cement and Concrete Research, 88, pp. 217-226, https://doi.org/10.1016/..cemconres.2016.05.013

[7] Mahoutian, M.; Shao, Y.; Mucci, A.; Fournier, B. 2015: Carbonation and Hydration Behavior ofEAF and BOF Steel Slag Binders, Materials and Structures, 48 (9), pp. 3075-3085, https://doi.org/10.1617/s11527-014-0380-x

[8] Shi, C. 2004: Steel slag-its production, processing, characteristics, and cementitious properties, Journal of Materials in Civil Engineering, 16 (3), pp. 230-236, https://doi.org/10.1061/(ASCE)0899-1561(2004)16:3(230)

[9] Barra, M.; Ramonich, E. V.; Munoz, M. A. 2001: Stabilization of soils with steel slag and cementfor application in rural and low traffic roads, Beneficial Use of Recycled Materials in Transportation Application, RMCR University of Durham, Arlington, VA, Nov. $13-15,2001$, pp. 423-432.

[10] Luxan, M. P.; Sotolongo, R.; Dorrego, F.; Herrero, E. 2000: Characteristics of the slags produced in the fusion of scrap steel by electric arc furnace, Cement and Concrete Research, 30 (4), pp. 517-519, https://doi.org/10.1016/S00088846(99)00253-7

[11] Manso, J. M.; Losanez, M.; Polanco, J. A.; Gonzalez, J. J. 2005: Ladle furnace slag in construction, Journal of Materials in Civil Engineering, 17 (5), pp. 513-518, https://doi.org/10.1061/(ASCE)0899-1561(2005)17:5(513) 
[12] Tossavainen, M.; Engstrom, F.; Yang, Q.; Menad, N.; Larsson, M. L.; Bjorkman, B. 2007: Characteristics of steel slag under different cooling conditions, Waste Management, 27, pp. 1335-1344, https://doi.org/10.1016/j.wasman.2006.08.002

[13] Tsakiridis, P. E.; Papadimitriou, G. D.; Tsivilis, S; Koroneos, C. 2008: Utilization of steel slag for Portland cement clinker production, Journal of Hazardous Materials, 152 (2), pp. 805-811, https://doi.org/10.1016/i.jhazmat.2007.07.093

[14] Johnson, D. C. 2000: Accelerated carbonation of waste calcium silicate materials, SCI Lect. Pap. Ser., 108, pp. 1-10, https://doi.org/10.1142/9789812793669_0001

[15] Moon, E. J.; Choi, Y. C. 2018: Development of carbon-capture binder using stainless steel argon oxygen decarburization slag activated by carbonation, Journal of Cleaner Production, 180, pp. 642-654, https://doi.org/10.1016/j.jdepro.2018.01.189

[16] Xuequan, W.; Hong, Z.; Xinkai, H.; Husen, L. 1999: Study on steel slag and fly ash composite Portland cement, Cement and Concrete Research, 29 (7), pp. 1103-1106, https://doi.org/10.1016/S0008-8846(98)00244-0

[17] Motz, H. 2002: Production and use of air-cooled blastfurnace and steel slags, 3rd Eur. Slag Conf. Keyworth, UK, 2002., pp. $7-20$.

[18] Baalamurugan, J.; Kumar, V. G.; Chandrasekaran, S.; Balasundar, S.; Venkatraman, B.; Padmapriya, R.; Raja, V. K. B. 2019: Utilization of induction furnace steel slag in concrete as coarse aggregate for gamma radiation shielding, Joumal of Hazardous Materials, 369, pp. 561-568, https://doi.org/10.1016/j.jhazmat.2019.02.064

[19] Netinger Grubeša, l.; Barišić, I. 2016: Environmental im pact analysis of heavy metal concentration in waste materials used in road construction, e-GFOS, 7 (13), pp. 23-29, https://doi.org/10.13167/2016.13.3

[20] Ferreira, V. J.; Vilaplana, A. S. D. G.; Armingol, T. G.; Usón, A. A.; González, C. L.; Sabirón, A. M. L.; Ferreira, G. 2016: Evaluation of the steel slag incorporation as coarse aggregate for road construction: technical requirements and environmental impact assessment, Journal of Cleaner Production, 130, pp. 175-186, https://doi.org/10.1016/i.jdepro.2015.08.094

[21] National Slag Association: Steel Slag: A Premier Construction Aggregate. Available: http://www.acobrasil.org.br/siderurgiaemfoco/CCABrasil/NSA\%20Steel\%20Furnace\%20Brochure.pdf (Accessed February 21, 2014)

[22] Mymrin, V. A.; Ponte, H.A.; Yamamoto, C. I. 2003: Synthesis of new colloidal formations during the strengthening of different activated hydrated metallurgical slags, Colloids and Surfaces A: Physicochemical and Engineering Aspects, 220 (1-3), pp. 211-21, https://doi.org/10.1016/S0927-7757(03)00070-0.

[23] Androjić, l.; Dimter, S. 2012: Compressive strength of steel slag stabilized mixes, Građevinar, 64 (1), pp. 15-21, https://doi.org/10.14256/JCE.626.2011

[24] Barišić, l.; Dimter, S.; Rukavina, T. 2014: Strength properties of steel slag stabilized mixes, Composites Part B, 58, pp. 386-391, https://doi.org/10.1016/..compositesb.2013.11.002

[25] Emery, J.: Steel slag utilization in asphalt mixes. National Slag Association Report MF 186-1. http://www.nationalslag.org/sites/nationalslag/files/documents/nsa 1861_steel_slag_utilization_in_asphalt_mixes.pdf (Accessed Mart31, 2019)

[26] Da Silveira, N. O.; Silva, M. V. A. M. E; Agrizzi, E. J.; De Lana, M. F.; Mendonca, R. L. D. 2004: ACERITA - Steel slag with reduced expansion potential, Revue de Métallurgie, 101 (10), pp. 779-785, https://doi.org/10.1051/metal:2004134

[27] Office of Research, Development, and Technology, Office of Infrastructure, RDT, Steel Slag, User guidelines for byproducts and secondary use materials in pavement construction, U.S. Department of Transportation Federal Highway Administration, FHWA-RD-97-148, https://www.fhwa.dot.gov/publications/research/infrastructure/pavements/97148/index.cfm (Accessed April 2, 2019)

[28] Emery, J. 1982: Slag utilization in pavement construction, Extending Aggregate Resources, W. Hotaling, Ed., West Conshohocken, PA: ASTM International, 1982, pp. 95-118, https://doi.org/10.1520/STP32459S

[29] Shen, D. H.; Wu, C. M.; Du, J. C. 2009: Laboratory investigation of basic oxygen furnace slag for substitution of aggregate in porous asphalt mixture, Construction and Building Material, 23 (1), pp. 453-461, https://doi.org/10.1016/j.conbuildmat.2007.11.001

[30] Lewis, D. W. 1982: Properties and uses of iron and steel slags, National Slag Association Report MF 182-6 presented at Symposium on Slag National Institute for Transport and Road Research, South Africa, Feb. 1982,http://www.nationalslag.org/sites/nationalslag/files/documents/nsa_182-6_properties_and_uses_slag.pdf (Accessed Mart 31, 2019)

[31] Reddy, K. R.; Gopakumar, A.; Chetri, J. K. 2019: Critical review of applications of iron and steel slags for carbon sequestration and environmental remediation, Reviews in Environmental Science and Bio/Technology, 18 (1), pp. 127152, https://doi.org/10.1007/s11157-018-09490-w 
[32] Ukwattage, N. L.; Ranjith, P. G.; Li, X. 2017: Steel-making slag for mineral sequestration of carbon dioxide by accelerated carbonation, Measurement, 97, pp. 15-22, https://doi.org/10.1016/j.measurement.2016.10.057

[33] Hu, B.; Chen, S.; Hu, J.; Xia, F.; Xu, J.; Li, Y.; Shi, Z. 2017: Application of portable XRF and VNIR sensors for rapid assessment of soil heavy metal pollution," PLoS One, 12 (2: e0172438), https://doi.org/10.1371/journal.pone.0172438

[34] Wuana, R. A.; Okieimen, F. E. 2011: Heavy metals in contaminated soils: a review of sources, chemistry, risks and best available strategies for remediation, ISRN Ecol., http://dx.doi.org/10.5402/2011/402647

[35] Xue, Y.; Hou, H.; Zhu, S. 2009: Competitive adsorption of copper (II), cadmium (III), lead (II) and zinc (II) onto basic oxygen furnace slag, Journal of Hazardous Materials, 162 (1), pp. 391-401, https://doi.org/10.1016/i.jhazmat.2008.05.072

[36] Zhao, X. L.; Masaihiko, S. 2007: Amelioration of cadmium polluted paddy soils by porous hydrated calcium silicate, Water, Air, and Soil Pollution, 183 (1-4), pp. 309-315, https://doi.org/10.1007/s11270-007-9379-z

[37] Ning, D.; Liang, Y.; Song, A.; Duan, A.; Liu, Z. 2016: In situ stabilization of heavy metals in multiple-metal contaminated paddy soil using different steel slag-based silicon fertilizer, Environmental Science and Pollution Research, 23 (23), pp. 23638-23647, https://doi.org/10.1007/s11356-016-7588-y

[38] Zhuo, L.; Li, H.; Cheng, F.; Shi, Y.; Zhang, Q.; Shi, W. 2012: Co-remediation of cadmium-polluted soil using stainless steel slag and ammonium humate, Environmental Science and Pollution Research, 19 (7), pp. 2842-2848, https://doi.org/10.1007/s11356-012-0790-7

[39] Moon, D. H.; Wazne, M.; Cheong, K. H.; Chang, Y. Y.; Baek, K.; Ok, Y. S.; Park, J. H. 2015: Stabilization of As-, Pb-, and Cu-contaminated soil using calcined oyster shells and steel slag, Environmental Science and Pollution Research, 22 (14), pp. 11162-11169, https://doi.org/10.1007/s11356-015-4612-6

[40] Gutierrez, J.; Hong, C. O.; Lee, B. H.; Kim, P. J. 2010: Effect of steel-making slag as a soil amendmenton arsenic uptake by radish (Raphanus sativa L.) in an upland soil, Biology and Fertility of Soils, 46 (6), pp. 617-623, https://doi.org/10.1007/s00374-010-0470-z

[41] Kimio, I. T. O. 2015: Steelmaking slag for fertilizer usage, Nippon Steel \& Sumitomo M etal, Chiba Perf., Japan, Technical ReportNo. 109, pp. 130-136,

[42] Gu, H. H.; Qiu, H.; Tian, T.; Zhan, S. S.; Chaney, R. L.; Wang, S. Z.; Tang, Y. T.; Morel, J. L.; Qiu R. L. 2011: Mitigation effects of silicon rich amendments on heavy metal accumulation in rice (Oryza sativa L.) planted on mult-metal contaminated acidic soil, Chemosphere, 83 (9), pp. 1234-1240, https://doi.org/10.1016/i.chemosphere.2011.03.014

[43] He, H.; Tam, N. F.; Yao, A.; Qiu, R.; Li, W. C.; Ye, Z. 2017: Growth and Cd uptake by rice (Oryza sativa) in acidic and Cd-contaminated paddy soils amended with steel slag, Chemosphere, 189, pp. 247-254, https://doi.org/10.1016/i.chemosphere.2017.09.069

[44] Ochola, C. E.; Moo-Young, H. K. 2004: Establishing and elucidating reduction as the removal mechanism of $\mathrm{Cr}(\mathrm{VI})$ by reclaimed limestone residual RLR (modified steel slag), Environmental Science and Technology, 38 (22), pp.6161-6165, https://doi.org/10.1021/es049670|

[45] Xiong, W.; Peng, J. 2008: Development and characterization of ferrihydrite-modified diatomite as a phosphorus adsorbent, Water Resources, 42 (19), pp. 4869-4877, https://doi.org/10.1016/i.watres.2008.09.030

[46] Bowden, L. l.; Jarvis, A. P.; Younger, P. L.; Johnson, K. L. 2009: Phosphorus removal from waste waters using basic oxygen steel slag, Environmental Science and Technology, 43 (7), pp. 2476-2481, https://doi.org/10.1021/es801626d

[47] Smith, J.: U.S. Patent No. 6,602,421. Washington, DC: U.S. Patent and Trademark Office, 2003.

[48] Name, T.; Sheridan, C. 2014: Remediation of acid mine drainage using metallurgical slags, Mineral Engineering, 64, pp. 15-22, https://doi.org/10.1016/i.mineng.2014.03.024

[49] El-Azim, H. A.; Seleman, M. M. E. S.; Saad, E. M. 2019: Applicability of water-spray electric arc furnace steel slag for removal of $\mathrm{Cd}$ and $\mathrm{Mn}$ ions from aqueous solutions and industrial wastewaters, Journal of Environmental Chemical Engineering, 7 (2), pp. 102915, https://doi.org/10.1016/j.jece.2019.102915

[50] Schuiling, R. D.; Krijgsman, P. 2006: Enhanced Weathering:An Effective and Cheap Tool to Sequester $\mathrm{CO}_{2}$, Climatic Change, 74 (1-3), pp. 349-354, https://doi.org/10.1007/s10584-005-3485-y

[51] Sarperi, L.; Surbrenat, A.; Kerihuel, A.; Chazarenc, F. 2014: The use of an industrial by-productas a sorbentto remove $\mathrm{CO}_{2}$ and $\mathrm{H}_{2} \mathrm{~S}$ from biogas, Journal of Environmental Chemical Engineering, 2 (2), pp. 1207-1213, https://doi.org/10.1016/i.jece.2014.05.002

[52] Huijgen, W. J.; Witkamp, G. J.; Comans, R. N. 2005: Mineral $\mathrm{CO}_{2}$ sequestration by steel slag carbonation, Environmental Science and Technology, 39 (24), pp. 9676-9682, https://doi.org/10.1021/es050795f

[53] Kasina, M.; Kowalski, P. R.; Michalik, M. 2015: Mineral carbonation of metallurgical slags, Mineralogia, 45 (1-2), pp. 2745, https://doi.org/10.1515/mipo-2015-0002

[54] Yu, J.; Wang, K. 2011: Study on Characteristics of Steel Slag for $\mathrm{CO}_{2}$ Capture, Energy Fuels, 25 (11), pp. 5483-5492, https://doi.org/10.1021/ef2004255 
[55] Pan, S. Y.; Chung, T. C.; Ho, C. C.; Hou, C. J.; Chen, Y. H.; Chiang, P. C. 2017: CO$_{2}$ Mineralization and Utilization using Steel Slag for Establishing a Waste-to-Resource Supply Chain, Scientific Reports, 7 (1), pp. 17227, https://doi.org/10.1038/s41598-017-17648-9

[56] Sas, W.; Głuchowski, A.; Radziemska, M.; Dzięcioł, J.; Szymański, A. 2015: Environmental and Geotechnical Assessment of the Steel Slags as a Material for Road Structure, Materials, 8 (8), pp. 4857-4875, https://doi.org/10.3390/ma8084857

[57] Gomes, J. F. P.; Pinto, C. G. 2006: Leaching of heavy metals from steelmaking slags, Revista de Metalurgia, 42 (6), pp. 409-416, https://doi.org/10.3989/revmetalm.2006.v42.i6.39

[58] Chaurand, P.; Rose, J.; Domas, J.; Bottero, J. Y. 2006: Speciation of Cr and V within BOF steel slag reused in road constructions, Journal of Geochemical Exploration, 88 (1-3), pp. 10-14, https://doi.org/10.1016/j.gexplo.2005.08.006

[59] Navarro, A.; Martínez, F. 2010: The use of soil-flushing to remediate metal contamination in a smelting slag dumping area: Column and pilot-scale experiments, Engineering Geology, 115 (1-2), pp. 16-27, https://doi.org/10.1016/j.enggeo.2010.07.001

[60] Barišić, l.; Netinger Grubeša, I.; Kutuzović, B. H. 2016: Multidisciplinary approach to the environmental im pact of steel slag reused in road construction, Road Materials and Pavement Design, 18 (4), pp. 897-912, https://doi.org/10.1080/14680629.2016.1197143

[61] Quaghebeur, M.; Nielsen, P.; Horckmans, L.; Mechelen, D. V. 2015: Accelerated Carbonation of Steel Slag Compacts: Development of High-Strength Construction Materials, Frontiers in Energy Research, 3, pp. 52, https://doi.org/10.3389/fenrg.2015.00052

[62] Proctor, D. M.; Shay, E. C.; Fehling, K. A.; Finley, B. L. 2002: Assessment of human health and ecological risks posed by the uses of steel-industry slags in the environment, Human and Ecological Risk Assessment: An International Journal, 8 (4), pp. 681-711, https://doi.org/10.1080/10807030290879907

[63] Piatak, N. M.; Parsons, M. B.; Seal II, R. R. 2015: Characteristics and environmental aspects of slag: A review, Applied Geochemistry, 57, pp. 236-266, https://doi.org/10.1016/i.apgeochem.2014.04.009

[64] Ringelband, U. 2001: Salinity Dependence of Vanadium Toxicity against the Brackish Water Hydroid Cordylophora caspia, Ecotoxicology and Environmental Safety, 48 (1), pp. 18-26, https://doi.org/10.1006/eesa.2000.1997

[65] Takahashi, T.; Yokoyama, S. 2016: Bioassay of Components Eluted from Electric Arc Furnace Steel Slag Using Microalgae Chlorella, ISIJ Internationa, 56 (8), pp. 1497-1505, https://doi.org/10.2355/isijinternational.ISIJINT-2015-539

[66] Wendling, L. A.; Douglas, G. B.; Coleman, S. 2012: Productive use of steelmaking by-product in environmental applications - II: Leachate geochemistry, ecotoxicity and environmental radioactivity, Minerals Engineering, 39, https://doi.org/10.1016/j.mineng.2012.07.010

[67] Hackenberger, D. K.; Feigl, V.; Lončarić, Ž.; Hackenberger, B. K. 2019: Biochemical and reproductive effects of red mud to earthworm Eisenia fetida, Ecotoxicology and Environtal Safety, 168, pp. 279-286, https://doi.org/10.1016/j.ecoenv.2018.10.097

Please cite this article as:

Stjepanović, N.; Hackenberger, D. K.; Hackenberger, B. K.; Zelić, L.: Usage of steel slag as a construction material and in environmental application, Electronic Journal of the Faculty of Civil Engineering Osijek-e-GFOS, 2019, 19, pp. 13-22, https://doi.org/10.13167/2019.19.2 